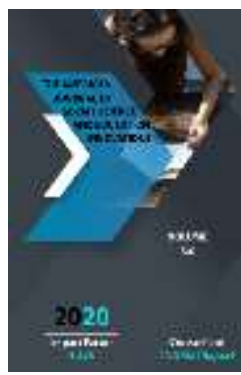

\title{
Relevance Of Digital Diplomacy Development In Modern International Relations
}

Mirsoatova Sh.

Tashkent State University Of Oriental Studies, Tashkent, Uzbekistan

Journal Website: http://usajournalshub.c om/index,php/tajssei

\section{ABSTRACT}

The article examines the issue of digital diplomacy in its context as a social life phenomenon and also attempts to rationally explain the necessity of its development.

\section{KEYWORDS}

Digital diplomacy, foreign policy, diplomatic tasks, information security, information space, information and communication technologies, USA, Russia, Twitter.

\section{INTRODUCTION}

Digital diplomacy is the use of the Internet and information and communication technologies to solve diplomatic problems. In addition to traditional media such as digital television and websites, the term "digital diplomacy" is often used to refer to the use of social networks to promote the country's foreign policy interests. However, despite the fact that digital diplomacy as a concept has already taken shape, many researchers often confuse the diplomatic dimension of information and communication technologies with such concepts as "information security", "information space", "propaganda" and so on.

There are many approaches to understanding this phenomenon, although most observers agree on one thing - digital diplomacy is a new reading of yesterday's "traditional" diplomacy. Of course, it is difficult to imagine how 
historical events would have developed if the Internet had existed in the modern era, and if Napoleon, Talleyrand or Metternich had their Twitter or Facebook accounts. However, history does not know the subjunctive mood, and therefore one thing is important diplomacy remains an important area of state policy, since it is diplomacy that provides operational and expert analysis that influences the formation of the point of view of the head of state and the steps of the state in foreign policy. Career diplomats assist the elite in unifying the points of view of different strata of society, conduct their selection, analyze often a huge array of information, evaluate and form appropriate conclusions. And it is hard to deny that in the information age, this remains relevant, as in previous eras.

Consider the phenomenon of digital diplomacy on the example of the popular social network Twitter. Although for many diplomats, Twitter has become a powerful information channel for digital diplomacy and state Affairs in the XXI century and not all Twitter exchanges are diplomatic, the realities of the modern world have a great impact on Twitter and sometimes cause real "hashtag wars". Nevertheless, the heads of foreign ministries and ministries on Twitter pay special attention to establishing mutual contacts with their colleagues on the Internet. So, in September 2013, the US State Department subscribed to the channels of 22 foreign ministries, as well as to the channel of Iranian President Hassan Rouhani (@HassanRouhani) and the Iranian foreign Minister(@JZarif), thereby slowly establishing diplomatic relations between the US and Iran on Twitter.

\section{MATERIALS AND METHODS}

In 2014, according to research conducted by the communication company "BursonMarsteller", the results of which are published on the website "Twiplomacy", which is dedicated to the issues of diplomacy on Twitter, the most popular diplomat who leads his blog is the French foreign Minister Laurent
Fabius (mutual subscription to 91 channels of colleagues and world leaders), the second place is the official Twitter of the European Union (71 subscriptions), and the third is the Swedish foreign Minister Karl Bild (68 subscriptions). Over the years, foreign ministries of various countries have significantly increased their networks of ambassadors, embassies, consulates and diplomatic missions on Twitter. According to a General list published on the @Twiplomacy channel, more than 3,100 embassies or their representatives conduct active "Twitter diplomacy". Obviously, mutual connections on Twitter help leaders write directly to each other and have private conversations. Many foreign ministries have used this communication channel to connect with colleagues and other influential people to ensure clear interaction or coordination of the digital presence.

In the XXI century, states are no longer at war with each other, and conflicts are mostly local in nature, and states tend to cooperate more with each other. Contrary to the apologists of realism from political science departments of various universities around the world, in a certain sense, the six principles of political realism by Hans Morgenthau have already lost their relevance, and today we see a large world, the different power centers of which are strongly interconnected. The latest waves of the global financial crisis are a clear proof of that and a strong argument against those who claim that conflicts between states are now conducted in the economic dimension.

In the current context of globalization and the acceleration of information and economic flows, States need to adapt to rapidly changing realities in order to survive as institutions. It should be noted that the events of September 11, 2001 put an end to the theory of promoting non-governmental organizations and multinational companies to the fore, actualizing the state as an institution that has already begun to lose its position as a regulator 
and controller of the daily life of human society. Since then, over the course of almost 20 years, states have changed significantly, including changing their modus operandi. Foreign policy and diplomacy have also changed.

States in their policies initially began to adhere to securitization of all possible aspects of public life (the adoption in the United States by the Bush administration of the so-called Patriot Act, "On uniting and strengthening America by providing the appropriate means required to prevent and prevent terrorism in 2001" was a vivid example of this, the consequences of which, regularly extended, are still felt).

Against this background, digital diplomacy was perceived as a relevant and effective tool for promoting US foreign policy goals. Using the example of the American state, former diplomat Wilson Dizard, in his book "Digital diplomacy: US foreign policy in the information age", published in the same year 2001, considers digital diplomacy as a tool for strengthening the power of the United States and highlights practical issues facing American diplomacy at that time, such as the inclusion of issues related to information technology and software in the agenda of negotiations on US defense and trade cooperation with other States, unification of the channels of exchange and processing of information of the US state Department, issues of public diplomacy and development of the telecommunications sector to help poor countries bridge the information gap and accelerate their development.

In this regard, other States are also keeping up with the United States and introducing elements of digital diplomacy in their foreign policy.

At the same time, in June 2012, at a meeting of ambassadors and permanent representatives, the Russian President ranked digital diplomacy among the most effective tools of foreign policy. V.Putin called on diplomats to make more intensive use of new technologies on various platforms, including social media, to explain the state's positions. In particular, he said that "the policy of "soft power" provides for the promotion of their interests and approaches by persuading and attracting sympathy for their country, based on its achievements not only in material, but also in spiritual culture and in the intellectual sphere".

\section{RESULT AND DISCUSSION}

Appointment of official representative of MFA of Russia Deputy Director of Department of information and press of the foreign Ministry Maria Zakharova, known for its activity on social networks - Facebook, etc., is undeniable proof that the Kremlin cannot remain aloof from modern trends in the information sphere, and relies on the modernization approach of the foreign Ministry, known for their conservatism from the Soviet era. Obviously, the Russian foreign policy establishment realized that against the background of events in Ukraine and Russia is beginning to lag behind in the information campaign, and therefore, as the former and Plenipotentiary Ambassador of Russia to Turkey Peter Stegny notes, in modern conditions, "the appearance of a person in explanatory work is a huge step forward for the Foreign Ministry".

As noted by M. Zakharova, the Russian foreign Ministry understands that "people of a certain age, professions, people who are used to working on the Internet - they simply do not like official press releases, they simply do not perceive them... Different audience - different language. It's not a slang language, it's not a thug language, it's the language of the blogosphere". However, in her blog on the website of Radio echo of Moscow, she emphasizes: "Given my recent appointment as an official representative of the Russian foreign Ministry, I would like to determine the status of my "blogging". Everything I write in social networks and blogs is not an official statement of the Russian foreign Ministry. For this purpose, there is a website of the Ministry 
of foreign Affairs and briefings and press conferences held in the Ministry. My posts are an expert opinion. A big request to the media to pay attention to this, let's say, nuance". Thus, the Russian foreign Ministry also does not stay away from the use of social networks in its "explanatory work".

However, at the same time, we must not forget that digital diplomacy in its newest form, namely, the use of social networks and Internet blogs by diplomats, is an important tool and the most effective tool of foreign policy when directly addressing an online audience with a specific information message. This allows you to find access to those segments of the population that previously fell out of the field of attention of the Ministry of foreign Affairs for various reasons.

One of these reasons is the dry and "official" language that is usually used to provide information about events or analytical data. This may be an acceptable way of communicating information in interdepartmental correspondence, but experts believe that this is absolutely unacceptable when addressing, say, a youth or rural audience, since the usual foreign Ministry official status does not arouse much enthusiasm and interest among these segments of the population. In addition, it is important to keep in mind the cultural and linguistic characteristics of the foreign audience.

\section{CONCLUSION}

Thus, digital diplomacy is a new and interesting dimension in foreign policy and is becoming a very effective tool in implementing the tasks facing the foreign policy departments of the world, namely, ensuring maximum transparency and timeliness of activities and processes, information content and interactive and open communication with the direct audience. In addition, each tool of digital diplomacy requires a delicate and special approach that changes in detail every day, which makes it difficult to develop and update, if any, a single state program for the development of ICT in the foreign ministries of various countries. It is obvious that this experience will be very useful for diplomats, in particular, since human society is developing rapidly in the information field, and lagging behind current trends in information communication will mean an inevitable lag in time.

\section{REFERENCES}

1. Chester A. Crocker, Fen Osler Hampson, Pamela Aall, "Leashing the Dogs of War: Conflict Management in a Divided World", United States Institute of peace, 2007, $800 \mathrm{pp}$.

2. Edward D. Mansfield and Brian $M$. Pollins, "Economic Interdependence and International Conflict: New Perspectives on an Enduring Debate", University of Michigan Press, 2003, 286 pp.

3. Hans J. Morgenthau, "Politics Among Nations: the Struggle for Power and Peace", McGraw-Hill Education, 7th ed., 2005, 752 pp.

4. $\quad$ Keohane, R.O., \& Nye, J.S. "Power and Interdependence in the Information Age". Foreign Affairs, 1998, 77(5), p. 81.

5. Wilson Dizard Jr., "Digital Diplomacy: U.S. Foreign Policy in the Information Age", Praeger, 2001, 223p.

6. Zinovyeva Ye. «Digital diplomacy: international security and opportunities for Russia», "Security Index» №1 (104), Vol. 19, p. 213-228.

7. http://www.unmultimedia.org/radio/ru ssian/archives/185093/

8. http://twiplomacy.com/blog/twiploma cy-study-2014/

9. https://www.congress.gov/bill/107thcongress/house-bill/3162

10. http://kremlin.ru/events/president/ne ws/15902

11. http://www.gazeta.ru/politics/2014/10/ 06_a_6250165.shtml 
The American Journal of Social Science and Education Innovations (ISSN - 2689-100x)

Published: October 31, 2020 | Pages: 400-404

12. http://echo.msk.ru/blog/mzakharova/

13. http://blogs.fco.gov.uk/digitaldiplomac yl 